\title{
Towards an anthropology of cultural mobilities
}

\section{ABSTRACT}

1.

2.

3.

4.

5.

6.

7.

8.

9.

10

11.

12.

13.

14.

15.

16.

17.

\begin{abstract}
Human mobilities, whether horizontal or vertical, internal or boundary-crossing, are infused with cultural meaning, manifested in metacultural discourses and imaginaries. While cultural elements clearly have an impact on people's mobility, the way people move across borders also exerts strong influence on their culture and society. Studying the interaction between culturally rooted imaginaries of mobility and real physical movements, a relation coloured by global media images as well as personal accounts, helps us understand the multiple meanings behind contemporary migratory phenomena. Cultural anthropology, as a discipline situated between the social sciences and the humanities, is ideally suited to analyse critically the complex dynamics between mobile cultures and human mobility. This article, based on longterm fieldwork in Tanzania, exemplifies what an anthropological take on the interplay between culture and mobility may look like. Placed in their wider historical and socio-economic context, I discuss migratory movements and their cultural representations in Tanzania. An analysis of the ethnographic data reveals how imaginaries and social relations concerning mobility are materialized, enacted and inculcated. The particular case of the Maasai people, who are entangled in an intricate web of cultural mobilities, illustrates the complexity of the issues at stake.
\end{abstract}

\section{KEYWORDS}

culture

mobility immobility anthropology ethnography Tanzania 
It is fashionable these days to imagine our lifeworld as being in constant motion, with not only objects and people, but images, ideas and cultures, too, travelling in every direction across the planet. The upsurge of scholarly interest in such mobilities, be they imagined or real, goes hand in hand with new theoretical approaches that reject a 'sedentarist metaphysics' (Malkki 1992) in favour of a 'nomadic metaphysics' (Cresswell 2006) and an increase in studies questioning the taken-for-granted bond between people, place and culture (Gupta \& Ferguson 1997). While previously academics tended to ignore or regard border-crossing movements as deviations from normative place-bound communities, cultural homogeneity and social integration, discourses of globalization and cosmopolitanism (that became dominant since the end of the Cold War) seem to have shifted the pendulum in the opposite direction; mobility being promoted as normality, and place attachment a digression or resistance against globalizing forces (Appadurai 1996). On the discursive level, mobile people have, for a long time, been used as one of the preferred concept-metaphors for social descriptions of both Self and Other in the social sciences and the humanities (Peters 2006). Still influential examples include Benjamin's (1999) flâneur, de Certeau's (1984) pedestrian, Said's (1993) (forced) migrant, and Deleuze's and Guattari's (1987) nomad. In fact, various notions of mobility have acted as dominant metaphors for rational thought, from de Montaigne to Rousseau (Van den Abbeele 1992), and many of the terms commonly used are marked by gender, class, ethnicity and culture (Benhabib \& Resnik 2009).

Notwithstanding the many kinds of involuntary or forced movements, mobility generally evokes a positive valence, denoting: (1) the ability to move; (2) the ease or freedom of movement; and (3) the tendency to change easily or quickly. This translates in three commonly held assumptions that have been widely spread via discussions about globalization: (1) there is (increasing) mobility; (2) mobility is a self-evident phenomenon; and (3) mobility generates change. Indeed, most cultural representations of mobility almost automatically link voluntary horizontal or geographical mobility with vertical economic (financial), social (status), and cultural (cosmopolitan) - 'climbing'. Although not always warranted (cf. Pajo 2007; Lindquist 2009), this connection is often made in the context of migration, an ongoing process involving the continuous circulation of people, social interactions and cultural expressions (Ong 1999). Migrants account for only a small part of the world population (estimates usually varying from two to ten per cent), but they form a substantial portion of all border-crossing people (International Organization for Migration 2008). Those who migrate do so for a number of reasons, a mixture of pressures from the social environment, market and immigration conditions, and personal as well as cultural traits and attitudes.

Despite the fact that collective migration and exodus are central to the foundation myths of various religions and cultures, in western societies migration and other forms of trans-border mobility have long been approached with distaste and suspicion (Cresswell 2006). This is partly due to the political system of nation-states, which set and control the parameters of (trans) national movements and prefer relatively immobilized and homogeneous subject populations. During the colonial era, degrees of mobility were used to differentiate people with and without culture: cultured people appeared 'sedentary and rooted in their particular niches', uncultured people were 'idealized as nomadic, rootless, and absolutely mobile' (Rosaldo 1988: 80). Cultural anthropologists, for their part, classically constituted cultures 'as essentially

1. 2. 3. 4. 5. 6. 7. 8. 9. 10. 11. 12. 13. 14. 15. 16. 17. 18. 19. 20. 21. 22. 
1. immobile or as possessing a mobility that is cyclical and repetitive [...] Those with culture are expected to have a regular, delimited occupation of territory. If they move, they must do so cyclically, like transhumant pastoralists or kularing sailors' (Tsing 1993: 123). Over a decade ago, Clifford (1997) convincingly argued that anthropology needs to leave behind its preoccupation with discovering the 'roots' of socio-cultural forms and instead trace the 'routes' that (re)produce them. Rather than culture being rooted in the earth (hence the close ties with agriculture), culture instead should be viewed as a site of both 'dwelling and travelling'.

Mobilities, whether across internal or external boundaries, clearly entail much more than mere movement; they are infused with cultural meaning (Frello 2008). While cultural elements partly determine how people are mobile, the way people move around also exerts strong influence on their culture and society (Casimir \& Rao 1992). Today, the perceived increase in cultural mobilities is one of the consequences and effects of movement and flexibility as demanded by the global capitalist system. However, throughout history, people have travelled vast distances, engaging in complex networks of cross-cultural exchanges and creating transcultural identifications. A sense of 'at-homeness' is often claimed to be the necessary condition for a robust cultural identity, but 'even in places that at first glance are characterized more by homogeneity and stasis than by pluralism and change, cultural circuits facilitating motion are at work' (Greenblatt 2009: 5). One could thus argue that cultures themselves are the product of a wide variety of boundary-crossing processes of exchange, processes that have also triggered counter-movements and have led to an increase in displayed cultural difference (Salazar 2010).

This article, then, analyses the complex dynamics between culture and human mobility. Using ethnographic data from long-term fieldwork in Tanzania, I explore how cultural factors shape border-crossing movements and how, in turn, trans-border mobilities reconfigure culture. By extending the research focus beyond borders, the role of imagined Otherness - both culturally and geographically - becomes more visible. Historically laden imaginaries are at the roots of many (if not all) voluntary movements to unknown destinations and metacultural assertions about such mobilities (cf. Urban 2001). These imaginaries travel through a multitude of channels, including people, and provide the cultural material to be drawn upon and used for the creation of translocal connections (Römhild 2003). Empowered by mass-mediated master narratives, imaginaries of mobility have become global; they are sent, circulated, transferred, received, accumulated, converted and stored around the world.

This is not just relevant for studying those who cross borders, but also those who, at least physically, remain firmly located within the limits of a particular place throughout their lives. Even when a person is place-bound, his or her imagination can be in movement, travelling to other places and other times (Rapport \& Dawson 1998). By extension, it could be argued that even when one is in movement, one's imagination can be focused on a singular place (e.g. diasporic people recreating their imagined 'homeland') and that these imaginaries of fixity can influence one's experience of mobility (Easthope 2009). What are the contours of power, agency and subjectivity in cultural imaginaries of global mobility and the intersecting social categories those visions both reify and dissolve? Are border-crossing movements more than the newest form of accumulating cultural capital? What are the cultural consequences of 'mobile cultures' and how do they sustain and challenge 
national identities? Who are the so-called 'immobile' and how are they creating their own culturally sanctioned forms of imaginative mobility? These are some of the pressing questions I address in this article.

\section{TANZANIAN TALES OF CULTURAL MOBILITY}

Research on migration as well as broader discourses on mobility - from the paleoanthropological Out-of-Africa hypothesis to the slave trade - have long been at the centre of African studies, not the least because mobility is considered a fundamental socio-cultural and historical aspect of African life (de Bruijn et al. 2001). Apart from daily mobilities (e.g. nomadic herding), border-crossing migration has been an integral part of labour markets and livelihoods across much of the African continent for at least the last century (Jónsson 2008). Over time, and in different places, it has taken a number of forms, including internal, regional and transnational movements, cutting across class and skill boundaries. Existing patterns, directions and motivations of human mobilities in Africa were severely affected by colonialism. Even if the colonial system did not introduce long-distance travels as a new feature in pre-colonial African societies, the character of migration and its effects on local societies changed fundamentally (Egerö 1979). Colonial imaginaries about African migratory movements in general, and conceptions of 'traditional' land tenure and patterns of settlement in particular, still have a huge influence over contemporary images and ideas of Africa (Bilger \& Kraler 2005). Anthropologists, too, have long been concerned with migration, movement and mobility in Africa (Salazar 2008). Over the years, their focus has shifted from movement impact studies on 'tribal' life (Colson 1971; Schapera 1947; Richards 1952) to analyses of how narratives about migration and mobility have moved to the centre of political discourse, and how claims over past or present migrations have turned into a pretext for exclusion (Comaroff \& Comaroff 2002) and studies on the local meanings of people's movements (Coplan 1994; Malkki 1992; Masquelier 2000). It is in the latter context that the importance of mobility imaginaries - socially shared schemas of cultural interpretation about migratory movements that mediate reality and help form identifications of Self and Other - comes to the fore.

In the cultural logics of migration, imaginaries play a predominant role in envisioning both the 'green pastures' and the (often mythologized) memory of the 'homeland'. Migration is as much about these imaginaries as it is about the actual physical movement from one locality to another and back. Migration always presupposes some knowledge or, at least, rumours of 'the other side'. The images and ideas of other (read: better) possible places to live - often misrepresented in popular culture - circulate in a very unequal global space (Englund 2002) and are ultimately filtered through people's personal aspirations. Although global capitalism may accelerate flexible mobility, imaginaries of such movements play out in uneven and even contradictory ways in the desires of people. Capital, gender and age largely determine the access potential migrants have to geographical mobility (United Nations Development Program 2009). In some cases, the dream of mobility works like a kind of opium; reality is no longer confronted and less people undertake concrete steps to migrate. The creative construction of this fantasy is one important factor leading some to even accept long-term unemployment at home, as they anticipate an eventual opportunity to journey abroad. Actual migratory movements often occur in phases, the geographic mobility being paralleled by (downward) social mobility between different migration statuses.
1. 2. 3. 4. 5. 6. 7. 8. 9. 10. 11. 12. 13. 14. 15. 16. 17. 18. 19. 20. 21. 22. 23. 24. 25. 26. 27. 28. 29. 30. 31. 32. 33. 34. 35. 36. 37. 38. 39. 40. 41. 42. 43. 44. 45. 46. 47. 48. 49. 50. 51. 52. 
In the case of post-independent Tanzania, various developments have implied a high level of human mobility in many parts of the country, both rural-rural and rural-urban migration, and involving agriculturalists as well as pastoralists (resulting in increased land pressure). Most contemporary migratory movements are internal and rural-urban, favouring circular mobility and permanent migration to commercial attraction poles like the coastal city of Dar es Salaam (National Bureau of Statistics 2006: 140-161). The small streams of emigration in the country's early postcolonial history consisted of labour migration to the Copperbelt in Zambia and to the Rand gold mines in South Africa, and people going to neighbouring Kenya and Uganda in search of either wage employment or land (Egerö 1979). Today's emigration is still insignificant, probably not exceeding 1 per cent of the population, with most migrants moving to nearby East African countries and only a very small group journeying all the way to Europe, the United States or the Middle East (Prinz 2005). In the global field of voluntary border-crossing mobilities, Tanzania is thus an extremely marginal player (it is a major actor, however, when it comes to welcoming refugees from neighbouring countries).

\section{GREENER PASTURES 'UP THERE'}

Despite the remarkably low rate of emigration, mobility imaginaries, especially of 'the West', are shared by large parts of the Tanzanian population. Majuu, literally 'the things up there' in Swahili, is often used as a synonym for Europe or the West. The 'up' is explained by Tanzanians as referring to the high living standard (implying distance from the daily life of most people), the orientation on a map (in the north), or the fact that they must fly to get to the West. In this context, 'the West' refers to a list of countries associated with certain features such as high level of development, wealth, social security and political power. The West does not stand for a specific geographic location with homogeneous cultural traits and historical background; it is rather a widespread dream, an act of imagination and an aspiration linked not only to a better education and more money but fame, victory, respect and admiration too (cf. Nyamnjoh \& Page 2002). Though few Tanzanians have actually travelled abroad themselves, many have close relatives or friends who have. As a result, most of the cultural tales about mobility are actually interpretations of other people's movements (Moyer 2003). These widely circulating imaginaries about majuu, sometimes mere rumours, centre on the United States, Europe, South Africa or Asia.

The imaginaries of migration to 'the West' (even if located north, east or south) derive from and are perpetuated by information from two main resources: global popular culture (mostly those forms circulating through mass media) and migrants or returnees. Not surprisingly, television is the most influential source. While Tanzania is one of the world's poorest countries, many of the programmes aired clearly offer fantasies of an aspirational lifestyle. Sometimes Tanzanian spectators do not realize that they are actually watching Latin-American telenovelas. For them, all stories take place in an imagined 'western' world. The consumption of these televised fantasies facilitates the imaginative construction of overseas migration as a solution to all their problems. Migration brokers, gatekeepers and middlemen (most often male) play an instrumental role in reifying the perceived dichotomy between 'here' and 'there': here things are bad, there things are better (at least so it seems). These Janus-like figures are often returnee migrants themselves. 
Youngsters share rumours about how these people come back refined, sophisticated, educated, and always well dressed. The perceived new authority and cosmopolitan identity acquired through the western experience has a huge effect on the migration imaginary.

Young Tanzanians join other Africans in their strong desire to belong to the promising cosmopolitan world 'out there' (Jónsson 2008; Ferguson 2006). Economic as well as social remittances and (often conspicuous) consumption by migrants easily increases the feeling of relative deprivation among non-migrants, and increases their aspirations to migrate as a way to achieve upward socio-economic mobility. The fact that migrants often have a tendency to present themselves as successful and to conceal their economic and social problems further fuels this. Both potential migrants and those who stay behind, however, often perceive economic opportunities and quality of life in 'the West' as greater than they actually are. Although most make more in wages than in their home countries, migrants are usually concentrated in lower-earning, lower-prestige jobs. Many even report downward social mobility after leaving their native homes. However, television, newspaper and personal accounts of destitution by African migrants abroad are no deterrent (Hahn \& Klute 2007), as every potential migrant either hopes to be luckier or to embrace the hardship which, by the standards of life in most of Africa, is imagined as paradise. This logic is part of a more globally spread 'culture of migration', or 'those ideas, practices and cultural artefacts that reinforce the celebration of migration and migrants. This includes beliefs, desire, symbols, myths, education, celebrations of migration in various media, and material goods' (Syed 2007: 39).

\section{MOVING FROM DREAM TO NIGHTMARE (AND BACK)}

The extremely low Tanzanian emigration rates stand in striking contrast to the thousands of other Africans trying to make the journey abroad each year as illegal migrants - risking people smugglers, deserts, sea crossings, and the possibility of being sent home, all for the dream of a better life. This is remarkable because, after all, there are a whole series of harsh realities - governmental policies, impoverished soils, drought, famine, and so on - that could compel Tanzanians to move away. Besides, most Africans rely on comparable migration rumours and entertainment media representations to build up imaginaries of mobility - some of which is real, and most of which is dreamt up (cf. Jónsson 2008). Why is it that in Tanzania migration imaginaries hardly generate excursions out of the homeland but that they merely encourage their emulation?

Apart from obvious reasons (e.g. the lack of capabilities, means and support to actually migrate), there are some other processes at work here. Few Tanzanians fancy calling another country their home. While they imagine majuu as a place preferable to their own country in terms of economics, they also offer critiques that illustrate that overseas migration is best envisioned as a temporary endeavour, undertaken mainly to improve one's life at home. In practice, the discourse of migratory mobility often remains just that, a discourse. While dreaming of migration is very important for young people's day-to-day life, travel abroad will not be a reality for most (cf. Weiss 2002). Besides, the majority now doubts that the greater part of African migrants in the West stand good chances to get a job with decent working conditions. Somehow, people start acknowledging that the spaces of marginality they want to escape from will reappear abroad. In earlier times, people may have

1. 2. 3. 4. 5. 6. 7. 8. 9. 10. 11. 12. 13. 14. 15. 16. 17. 18. 19. 20. 21. 22. 23. 24. 25. 
1. greatly over-estimated the impact of migration and conceptualized these in terms of their worldview and expectations for their future. Nowadays, things seem to have changed. Youngsters seem better informed and have a more critical mindset than before.

Many people I interviewed in Dar es Salaam and Arusha echoed the following explanations: 'Migration is not a very Tanzanian thing to do [...] After all, it's a nice country to live in'; 'Going far away isn't a thing to do [...] Maybe it all has to do with tradition'; 'Tanzanians are not the most ambitious people and they usually have a family they can rely upon'; 'Tanzanians are fearful, we don't have a mentality of conquering'. The relevance of such culturallyinflected testimonies lies in the very images and categories people use to describe and situate themselves within changing social worlds. They reaffirm that all mobilities are 'imaginatively crafted through particular cultural lenses' (Sanders 2001: 27). This way of thinking is also reflected in the messages spread around by the increasing number of Tanzanian media productions (created locally or in the Diaspora), which are very influential in shaping imaginaries, especially among young Tanzanians.

Bongo Flava (or Fleva, from the English 'flavour'), a popular style of music that was originally modelled on American hip hop, is enormously popular among Tanzanian youth. Itself a nice illustration of cultural mobility, the style mushroomed in the 1990s, thanks to the free market and the privatisation of the media. Bongo (the augmentative form of ubongo, brain) refers to the 'big brain' or cunningness necessary to survive in Tanzania (Bongoland). Interestingly, many songs critically address the issue of migration. John Walker and Ras Lion's (2007) song Bitozi (slang term to denote a 'cool person'), is a perfect example. The lyrics admonish youngsters to stop living in a dream world, and suggest that hard work at home is a better guarantee to success than foolish migration plans. In Uhamiaji ('Migration'), Dr John (2007) criticizes the bureaucracy in Tanzanian migration offices. One fan of the song left the following telling comment on its YouTube site (http://www.youtube.com/ watch?v=GK2oh1qPsEU): 'Yes man, I am in Europe, in the United Kingdom. It's up to the Tanzanians to build their home in Tanzania. I'm a Somali but born in Tanzania. Europe, Europe, Europe, it's a gamble [...] not all people can be successful' (own translation).

Similarly, in Mkoloni's (2000) Tajiri na Masikini ('Rich Person and Poor Person'), a poor person is not at all impressed by a rich person who brags about his children studying in Europe and he himself often travelling there. Ally Kiba's (2007) song Mac Muga tells the tale of a fellow Tanzanian singer, Mr. Nice (alias Lucas Mkenda), who wasted his fame and millions moving to South Africa and the United Kingdom, squandering his money on women and the high life. Now the man is back in Tanzania and has nothing to show off. Some of the YouTube comments on the lyrics are revealing (http://www. youtube.com/watch? $\mathrm{v}=93 \mathrm{~b} 1 \mathrm{NB} 5 \mathrm{XrKE}$ ): "This is about reality and responsibility', 'So simple yet so real. [...] hope people in the Diaspora are listening', 'The Mac Mugas of USA and Europe should listen to these lyrics [...] Nyumbani ni nyumbani jamani. Hebu mrejee b4 its too late!' (Home is home friends. Well, come back before it's too late!)

Inspired by Nollywood home videos from Nigeria, an increasing number of locally produced VCD films (sometimes dubbed Tollywood movies) equally address the issue of mobility imaginaries. The Swahili comedy Welcome Back (West 2007), for instance, tells the story of a Tanzanian businessman coming back from Europe with a German girlfriend (played by a German Ph.D. 
student in anthropology who studies Tanzanian movies). However, it's hard to keep up appearances when the woman discovers that he has a Tanzanian family and that he lives far more modestly than he claimed (and imagined). In a similar vein, Yebo Yebo (slang denoting a combination between hallo and yes) is a comedy about a Tanzanian migrant returning from the United States, while The Stolen Will (Game 2008) handles the theme of Tanzanians relying on relatives in Europe or the United States. In Dar 2 Lagos (Ogedegbe 2007), a Nigerian-Tanzanian coproduction (combining Nollywood and Tollywood actors), a Tanzanian goes to Nigeria searching for relatives who migrated there. One of the most remarkable Tanzanian VCD productions so far is the recently released Chinese-Tanzanian co-production From China with Love (Rajab 2008). It tells the unlikely tale about a Maasai businessman who falls in love with a Chinese girl he meets on a business trip to China. He brings the girl back home to marry her but the couple faces many problems, many of which have to do with cross-cultural communication difficulties. While this is an acknowledgment of the fact that these days Tanzanians also travel increasingly east, China and the Chinese are viewed rather negatively as people in general feel increasingly cheated by (cheap but unreliable) Chinese products that have pervaded the Tanzanian markets and shops (another, yet negatively valued, form of mobility).

Despite some exceptions, and notwithstanding increasing opportunities for Tanzanians to migrate to Uganda, South Africa, India, the Middle East and Egypt, the predominant migration imaginaries remain remarkably centred on 'the West' as the preferred locus to accrue symbolic capital and cosmopolitan status. In other words, the mainstream imaginary of mobility, the desire to belong to a global cosmopolis, has to be qualified because it is clearly directional. As indicated above, some of the Tanzanians I interviewed suggest there is a growing category of young people, mainly informed by migration narratives and rumours from returnees and new entertainment media representations, who do not really want to go abroad, but merely dream about the possibility. Yet, the recent Obama-mania (which hit Tanzania as much as it did many other parts of the world) shows that drawing such a conclusion might be precarious. It is not unlikely to suspect that Obama's election as President of the United States has reinvigorated the imaginary that the American dream can also be realized by African migrants: 'Yes we can!'

\section{THE MAASAI, PARADOXICAL ICONS OF (IM)MOBILITY}

Since most of the migratory movements of Tanzanians take place inside the borders of the nation-state, it is important to explore some of the images and ideas related to these internal mobilities too. In Tanzania, as elsewhere, different categories of mobile people are valued differently. On the one hand, minority ethnic groups such as the Chagga (Mt. Kilimanjaro area) and the Haya (area west of Lake Victoria) are looked up to for their lucrative trading networks across the country. On the other hand, colonial as well as postcolonial policies based on a metaphysics of sedentarism have equated pastoral nomads with backwardness - very similar to how the Romani and other Traveller people are treated in Europe or the Fulbe, Fulani or Peul in West Africa. This becomes painfully clear in the case of the Maasai people (Salazar 2009a; Schneider 2006). The Maasai, speakers of the Eastern Nilotic Maa tonal language, are a widely dispersed ethnic group of semi-nomadic pastoralists and small-scale subsistence agriculturists who occupy arid and semi-arid

1. 2. 3. 4. 5. 6. 7. 8. 9. 10. 11. 12. 13. 14. 15. 16. 17. 18. 19. 20. 
1. rangelands in southern Kenya and northern Tanzania - collectively known as Maasailand. In Tanzania, where there are around 400,000 Maasai, they are said to have lived in the whole of the Serengeti plains and Ngorongoro highlands for some two centuries.

Due to cultural representations that are circulating across the globe in countless coffee-table books, movies, and snapshots, everybody seems to 'know' the Maasai. Through their powerful (and stereotyped) media image, the Maasai have become icons of African traditionalism and unwitting symbols of resistance to modernist values (read: social immobility). The sight of a virile Maasai warrior, dressed in colourful red blankets and beaded jewellery, evokes the romantic image of a modern noble savage - a priceless tourism attraction. The majority of foreign tourists who visit Tanzania come to witness a unique form of trans-border mobility, not of the Maasai but the cyclical 'Great Migration' of millions of wildebeests and other grazing herbivores across the Serengeti-Mara ecosystem (Salazar 2009b). The wild plains of this wildlife landscape have become popular icons for Africa as a whole in the form of nature documentaries, Hollywood entertainment and autobiographic movies, with their perfect romantic and nostalgic vision of an unexplored wild Eden (Salazar 2010). Humans are remarkably absent in these imaginaries, although over 60,000 Maasai, for example, live inside the renowned Ngorongoro Conservation Area (they were forcefully moved there in 1959, with the establishment of Serengeti National Park). When they are talked about, it is often in an animal-like fashion (a creation of the colonizer's imagination). Take, for instance, the spectacular IMAx production Africa: The Serengeti (Casey 1994), in which the migration of wildebeests and zebras is compared to the nomadic existence of 'the proud Maasai people, ever seeking good grazing for their cattle herds'. The documentary focuses on the exotic warrior diet - a mixture of milk and blood - and puts the Maasai in a time-frozen past by stressing how, 'once the most formidable warriors in East Africa, the Maasai still defend their cattle and families with spears'.

Despite persisting colonial imaginaries that heavily romanticize the Maasai's perceived freedom from authority and closeness to nature, specialized pastoralism, traditionally at the core of Maasai cultural identity, has declined throughout the twentieth century (Spear \& Waller 1993; Homewood et al. 2009). While in the pre-colonial era, pastoralist migrations (ranging from daily herd movement to seasonal transhumance or migration) were limited principally by disease and more occasionally by insecurity, colonial and postcolonial policies added the occupation of land by cultivators, wildlife and new boundaries that impede free passage. The fact that the colonial powers seemed to have such a hard time 'domesticating' the Maasai was explained away by now well-refuted ethnocentric pseudo-scientific writings that argued that peoples like the Maasai were not indigenous (docile and immobile) Africans but migrants who came from the north (e.g. as wandering Jews) (cf. Rekdal 1998). In a work described as of the highest scientific value and great colonial interest, The Masai: Ethnographic Monograph of an East African Semite People (1910 [1904]), Merker noted significant parallels between the Maasai's myths and customs and those of the biblical Hebrews. Merker, a German military officer who lived and travelled among the Maasai in German East Africa (later Tanganyika) from 1895 to 1903 , concluded that both the Maasai and the 'oldest' Hebrews originated from the same people.

Such ideas were a reflection of a more widespread ideology circulating in Europe at the end of the nineteenth century, whereby the myth of the Lost Tribes 
developed as a useful channel for understanding unknown peoples and races, as a means of labelling human entities for which there was no readily available label. Ethnographers, alongside missionaries and travellers, time and time again concluded that African tribes, not only the Maasai, but also the Zulus, the Xhosa, the Hottentots, the Tutsis, the Ashanti and many more, were of Jewish origin. This served to legitimize European intervention and colonization. Ironically, some Maasai have appropriated these fabricated European imaginaries as their myth of origin. Many Maasai tour guides will now happily and proudly tell their foreign visitors that they are one of Israel's lost tribes (and some even refer to recent genetic research in the United States to prove their case).

Apart from restrictive (post-)colonial policies that constrained Maasai mobilities (e.g. due to the creation and expansion of national parks), tourism has also (economically) pushed many nomadic Maasai to lead a more sedentary life. If Maasai are at all engaged in tourism, it is usually in lower-paid jobs. A development within Maasai bomas (settlements), along heavily trodden tourism circuits, is the permanent presence of the warrior age-group (ilmurran). These young men play an important role in performing dances and seem to be extending their interests into the market place, whereas traditional customary practice stipulated that they should live together in their own manyatta, a temporary camp in surrounding bush areas - a kind of liminal phase of life allowing them to detach themselves from their family and become independent, mature individuals. Nowadays, Maasai youngsters hang around the bomas and show off their recently gained social mobility by using cell phones (the ultimate symbol of mobility), smoking cigarettes with filters, wearing socks and shoes, or putting on watches (items that are often hidden the moment tourists shows up). Paradoxically, their aspirations of moving socially upward - becoming more modern and western - can only materialize if they represent to tourists the lifeworld in which they live as developing little or not at all (Salazar 2006).

Not only Maasai culture in general is changing; some Maasai themselves are exploring new horizons. While a long-term tradition of movement is considered a precondition for what scholars have termed a 'culture of migration' (Kandel \& Massey 2002), it is important to stress that for pastoralists such as the Maasai herd mobility traditionally did not imply household mobility. Contemporary migration patterns are affected by environmental conditions, government policies, new technologies and public services. While some Maasai head south, going as far as Zambia, where they try to sell their medicines and their services as traditional healers, many more head toward the big urban centres. In the coastal town of Dar es Salaam and on the beaches of Zanzibar, the places where most of the package tourists stay, there are many young Maasai. Attracted by potential employment opportunities, unemployed up-country Maasai have migrated to these coastal areas to find risky, poorly paid, unskilled, casual work. Benefiting from their colonial image as fearless and warrior-like, they take up jobs as night watchmen or security guards, sell artefacts and adornments along the beach or in towns, and perform traditional dances in hotels.

In Zanzibar's Stone Town, for example, there are plenty of Maasai tourist art traders. They all migrated from the northern districts of Arusha and Kilimanjaro, basically following the tourist movements. Many of them were first employed as walinzi ('guardians') in hotels. However, being extremely popular with tourists who tour the national parks in the north of Tanzania, they became an attraction themselves and now perform for tourists. Most have been in the tourism souvenir trade for a while and travel regularly between the mainland and Zanzibar. Quite a number of them got into tourism in the

1. 2. 3. 4. 5. 6. 7. 8. 9. 10. 11. 12. 13. 14. 15. 16. 17. 18. 19. 20. 21. 22. 23. 24. 25. 26. 27. 28. 29. 30. 31. 32. 33. 34. 35. 36. 37. 38. 39. 40. 41. 42. 43. 44. 45. 46. 47. 48. 49. 50. 51. 52. 
1. mid-1990s, impelled by livestock losses from disease, severe drought and land alienation. Interestingly, most of Stone Town's Maasai or Maasai-style tourist art is actually made by Zanzibari people. The Maasai men who make beaded jewellery are a cultural oddity because, in their own culture, beading is a woman's task. Recently, also Tanzanian Maasai women started migrating from Maasailand to Dar es Salaam and other cities, even as far as Zanzibar, Kampala, and Nairobi. They produce and sell beads and traditional medicines for cash to support their families.

This phenomenon of increased circular migration is indicative of an overall intensifying impoverishment of the Maasai (Coast 2002). Only very few migrated for frivolous reasons, and those few are seen by others as deviants, likely to stay in town and become 'lost' to the more traditional Maasai community (May 2002). Many Maasai blame the recent decline in economic circumstances on their lack of schooling. Formal education was historically shunned, partly due to the mobile life style, and also because the relevance of it for pastoralism was not evident. Young ilmurran who travel to the coast to become 'beach boys' may expand the sense of roaming adventure long associated with their age grade, but elders are concerned about their moral decline from encounters with western tourists (Hodgson 2001). The new migrants usually profess a profound dislike for life in the city, and an expressed goal to earn enough to replenish their shrunken livestock herds and return home; a wish to remain pastoralists (albeit not in a traditional way, but making use of modern commodities and new information and communication technologies) and politically as well as socio-culturally independent. Despite the strong Maasai cultural identity, they may cease to be pastoralists, at least in economic terms. As well as lack of opportunities, perceptions of shame may constrain unsuccessful migrants from returning to their natal home.

Other urban citizens express condescending views of the Maasai migrants, typifying them as 'unmodern' and as curious young warriors who are lazy, naive, drunk and dirty (May \& Ole Ikayo 2007). Although various policies have been developed over the last century to try to 'develop' and settle the Maasai (Schneider 2006), their nomadic image is widely used as part of an instrumentalist agenda (including tourism advertising). Lacking political or social capital, the Maasai themselves manipulate and reinforce their ethnic identity by continuing to wear traditional garments, and by engaging in practices that emphasize their difference from other Tanzanians, bolster cohesion and solidarity among themselves, and increase their chances of urban employment. Their migrations lead to other inchoate cultural shifts and adaptations, such as delayed marriage and, conversely, of men marrying younger than is customary, as a strategy by their families to ensure they would return home after migration. Thus, while retaining its distinctiveness in stressful circumstances (e.g. by creating new forms of old 'traditions' in urban settings), Maasai culture exhibits a multiple as well as flexible nature. Maasai culture is simultaneously both reproduced and contested, going against the lingering representations of immutable and unreasoning Maasai 'rigidity'.

\section{CONCLUSION}

While Africa has long been described as an immensely mobile continent and continues to be viewed in this vein, there is a marked decline of Africa's share of international migrants (International Organization for Migration 2008). Most analyses explain this by referring to the widespread economic decline, 
the still rather negligible share of African migrants in western countries, and the recent stabilisation of the number of refugees in Africa. The findings discussed in this article, however, suggest that border-crossing migration is something quite different from mobility in general; a decline of international migration may well go hand in hand with rising mobility levels nationally and regionally. Most importantly, all forms and types of mobility are deeply embedded in wider cultural and socio-economic structures and, thus, mobility always needs to be analysed in the specific context in which it occurs. This article, for instance, illustrates that migration clearly has an instrumental role, but one which is guided by mobile cultural imaginaries more than mere economic considerations as such.

Only a tiny fraction of Tanzanians heads towards 'the West', but the fantasy to migrate there is quite popular. For people in Tanzania, such imaginaries of the 'good life' serve as an essentially creative act that facilitates their ability to move beyond existing structural imbalances of power and economic constraints. Increased global mobility of goods and ideas (spreading via new means of communication) enables them to desire the signs and styles of a global cosmopolitan order, while facing ever-narrower means by which to satisfy them (e.g. by becoming geographically mobile themselves). Highly desired cultural goods may only be accessed within particular spaces, and that isolation often creates struggles over the right to imagine possible futures. This becomes dramatically clear when considering the cultural (im)mobilities of the Maasai people. On the one hand, people witness the widening of their horizons, to new stimuli for the imagination; on the other they suffer from a chronic lack of means. In sum, cultural imaginaries - whether true or false, or somewhere in between - have real enough effects. Importantly, imaginaries are so widespread and popular because they give people at least some feeling of control in a world where they increasingly feel controlled.

As this article has illustrated, human mobilities - be they physical or imaginative - are moulded by cultural knowledge and practices. Culturally rooted understandings of mobility, coloured by media images as well as personal accounts, in interaction with physical movements, are important in attempts to explain migratory phenomena. Cultural anthropology fruitfully contributes to this field of inquiry by ethnographically detailing how mobility is a contested ideological construct involving much more than mere movement but is culturally embedded, manifested in metacultural discourses and imaginaries. It can, for instance, assess how imaginaries and social relations concerning mobility are materialized, enacted and inculcated. Instead of asking what migration does, or how it comes about, or how it is structured, a cultural mobilities approach to migration is concerned with how personal migratory experiences are tied into the cultural web of ongoing discourses of belonging, separation and achievement, power, nationalism and transnationalism.

We urgently need more systematic comparative studies of how cultural mobilities are generated in everyday life and facilitated as well as constrained by specific circuits and institutions. The mobility of cultures is brought about not only by past and contemporary diasporic and migratory movements of people, but also by the technological innovations that have made possible travels of the imagination, thus enabling people who are stuck in one place to be influenced by ongoing political, economic and cultural transformations elsewhere. Migratory movements have created new avenues for the transnational flow of identities, ideas and practices. An anthropology of mobility imaginaries - narratives and ideas that depend on the creation of the

1. 2. 3. 4. 5. 6. 7. 8. 9. 10. 
otherness of one's own identity as well as of the Other - reveals how mobile local lifeworlds are always negotiated and contested, and constantly under transformation.

\section{ACKNOWLEDGEMENTS}

This article is based on ongoing ethnographic research supported by grants from the National Science Foundation (Grant No. BCS-0514129), the European Commission (PIRG03-GA-2008-230892) and the Research Foundation Flanders (1.2.210.09.N). I thank my Tanzanian research assistant, Joseph Ole Sanguyan, for his invaluable feedback and support while carrying out the fieldwork for this article.

\section{REFERENCES}

Abbeele van den, Georges (1992), Travel as metaphor: From Montaigne to Rousseau, Minneapolis: University of Minnesota Press.

Appadurai, Arjun (1996), Modernity at large: Cultural dimensions of globalization, Minneapolis: University of Minnesota Press.

Benhabib, Seyla and Resnik, Judith (eds) (2009), Migrations and mobilities: Citizenship, borders, and gender, New York: New York University Press.

Benjamin, Walter (1999), The arcades project, Cambridge: Belknap Press.

Bilger, Veronika and Kraler, Albert (2005), 'African migrations: Historical perspectives and contemporary dynamics', Stichproben: Wiener Zeitschrift für kritische Afrikastudien, 8, pp. 5-21.

Bruijn, Mirjam de, van Dijk, Rijk and Foeken, Dick (eds) (2001), Mobile Africa: Changing patterns of movement in Africa and beyond, Leiden: Brill.

Casey, George (1994), Africa: The Serengeti, Hollywood: Graphic Films.

Casimir, Michael J. and Rao, Aparna (eds) (1992), Mobility and territoriality: Social and spatial boundaries among foragers, fishers, pastoralists, and peripatetics, New York: Berg.

Certeau, Michel de (1984), The practice of everyday life, Berkeley: University of California Press.

Clifford, James (1997), Routes: Travel and translation in the late twentieth century, Cambridge: Harvard University Press.

Coast, Ernestina (2002), 'Maasai socioeconomic conditions: A cross-border comparison', Human Ecology, 30: 1, pp. 79-105.

Colson, Elizabeth (1971), The social consequences of resettlement: The impact of the Kariba resettlement upon the Gwembe Tonga, Manchester: Institute for African Studies.

Comaroff, Jean and Comaroff, John L. (2002), 'Alien-Nation: Zombies, Immigrants, and Millennial Capitalism', The South Atlantic Quarterly, 101: 4, pp. 779-805.

Coplan, David B. (1994), In the time of cannibals: The word music of South Africa's Basotho migrants, Chicago: University of Chicago Press.

Cresswell, Tim (2006), On the move: Mobility in the modern Western world, New York: Routledge.

Deleuze, Gilles and Guattari, Félix (1987), A thousand plateaus: capitalism and schizophrenia, Minneapolis: University of Minnesota Press.

Dr John (2007), Uhamiaji, Dar es Salaam: Wagosi wa Kaya.

Easthope, Hazel (2009), 'Fixed identities in a mobile world? The relationship between mobility, place, and identity', Identities: Global Studies in Culture and Power, 16: 1, pp. 61-82. 
Egerö, Bertil (1979), Colonization and migration: A summary of border-crossing movements in Tanzania before 1967, Uppsala: Scandinavian Institute of African Studies.

Englund, Harri (2002), 'Ethnography after globalism: Migration and emplacement in Malawi', American Ethnologist, 29: 2, pp. 261-286.

Ferguson, James (2006), Global shadows: Africa in the neoliberal world order, Durham: Duke University Press.

Frello, Birgitta (2008), 'Towards a discursive analytics of movement: On the making and unmaking of movement as an object of knowledge', Mobilities, 3: 1, pp. 25-50.

Game, Mtitu G. (2008), The stolen will, Dar es Salaam: Game 1st Quality Tanzania Limited.

Greenblatt, Stephen (ed.) (2009), Cultural mobility: A manifesto, Cambridge: Cambridge University Press.

Gupta, Akhil and Ferguson, James (eds) (1997), Culture, power, place: Explorations in critical anthropology, Durham: Duke University Press.

Hahn, Hans Peter and Klute, Georg (eds) (2007), Cultures of migration: African perspectives, Berlin: Lit.

Hodgson, Dorothy L. (2001), Once intrepid warriors: Gender, ethnicity, and the cultural politics of Maasai development, Bloomington: Indiana University Press.

Homewood, Katherine, Kristjanson, Patricia and Trench, Pippa (eds) (2009), Staying Maasai? Livelihoods, conservation, and development in East African rangelands, London: Springer.

International Organization for Migration (2008), World migration 2008: Managing labour mobility in the evolving global economy, Geneva: International Organization for Migration.

Jónsson, Gunvor (2008), Migration aspirations and immobility in a Malian Soninke village, Oxford: International Migration Institute.

Kandel, William and Massey, Douglas S. (2002), 'The culture of Mexican migration: A theoretical and empirical analysis', Social Forces, 80: 3, pp. 981-1004.

Kiba, Ali (2007), Mac Muga, Dar es Salaam: G Records.

Lindquist, Johan A. (2009), The anxieties of mobility: Migration and tourism in the Indonesian borderlands, Honolulu: University of Hawai'i Press.

Malkki, Liisa H. (1992), 'National Geographic: The rooting of peoples and the territorialization of national identity among scholars and refugees', Cultural Anthropology, 7: 1, pp. 24-44.

Masquelier, Adeline (2000), 'Of headhunters and cannibals: Migrancy, labor, and consumption in the Mawri imagination', Cultural Anthropology, 15: 1, pp. 84-126.

May, Ann (2002), 'Unexpected migrations: Urban labour migration of rural youth and Maasai pastoralists', Ph.D. dissertation, Boulder: University of Colorado.

May, Ann and Ole Ikayo, Francis N. (2007), 'Wearing Illkarash: Narratives of image, identity and change among Maasai labour migrants in Tanzania', Development and change, 38: 2, pp. 275-298.

Merker, Moritz (1910 [1904]), Die Masai: Ethnographische Monographie eines ostrafrikanischen Semitenvolkes, Second edition, Berlin: Dietrich Reimer.

Mkoloni (2000), Tajiri na masikini, Dar es Salaam: Aegies.

Moyer, Eileen M. (2003), 'In the shadow of the Sheraton: Imagining localities in global spaces in Dar es Salaam, Tanzania', Ph.D. Dissertation, Amsterdam: University of Amsterdam. 
National Bureau of Statistics (2006), Tanzania census 2002: Analytical report, Dar es Salaam: National Bureau of Statistics.

Nyamnjoh, Francis B. and Page, Francis (2002), 'Whiteman kontri and the enduring allure of modernity among Cameroonian youth', African Affairs, 101: 405, pp. 607-634.

Ogedegbe, Femi (2007), Dar 2 Lagos, Dar es Salaam: Game 1st Quality Tanzania Limited.

Ong, Aihwa (1999), Flexible citizenship: The cultural logics of transnationality, Durham: Duke University Press.

Pajo, Erind (2007), International migration, social demotion, and imagined advancement: An ethnography of socioglobal mobility, New York: Springer.

Peters, John D. (2006), 'Exile, nomadism and Diaspora: The stakes of mobility in the western canon', in J. Morra \& M. Smith (eds), Visual culture: Spaces of visual culture, London: Taylor \& Francis, pp. 17-41.

Prinz, Vanessa (2005), "'Imagine migration": The migration process and its destination Europe in the eyes of Tanzanian students', Stichproben: Wiener Zeitschrift für kritische Afrikastudien, 8, pp. 119-140.

Rajab, Hamie (2008), From China with love: Penzi mwanana, Dar es Salaam: Tollywood.

Rapport, Nigel and Dawson, Andrew (eds) (1998), Migrants of identity: Perceptions of home in a world of movement, Oxford: Berg.

Rekdal, Ole Bjørn (1998), 'When hypothesis becomes myth: The Iraqi origin of the Iraqw', Ethnology, 37: 1, pp. 17-38.

Richards, Audrey I. (1952), Economic development and tribal change: A study of immigrant labour in Buganda, Cambridge: East African Institute of Social Research.

Römhild, Regina (2003), Practised imagination: Tracing transnational networks in Crete and beyond, Frankfurt: Research Group Transnationalism.

Rosaldo, Renato (1988), 'Ideology, place, and people without culture', Cultural Anthropology, 3: 1, pp. 77-87.

Said, Edward W. (1993), Culture and imperialism, New York: Knopf.

Salazar, Noel B. (2006), 'Touristifying Tanzania: Global discourse, local guides', Annals of Tourism Research, 33: 3, pp. 833-852.

Salazar, Noel B. (2008), 'Grounding mobility: Rethinking the boundaries of our world and work', 10th Biennial Conference of EASA, Ljubljana, Slovenia, 25-29 August.

Salazar, Noel B. (2009a), 'Imaged or imagined? Cultural representations and the "tourismification" of peoples and places', Cahiers d'Études Africaines, 193-194, pp. 49-71.

Salazar, Noel B. (2009b), 'A troubled past, a challenging present, and a promising future? Tanzania's tourism development in perspective', Tourism Review International, 12: 3-4, pp. 259-273.

Salazar, Noel B. (2010), Envisioning Eden: Mobilizing imaginaries in tourism and beyond, Oxford: Berghahn.

Sanders, Todd (2001), 'Territorial and magical migrations in Tanzania', in M. de Bruijn, R. van Dijk \& D. Foeken (eds), Mobile Africa: Changing patterns of movement in Africa and beyond, Leiden: Brill, pp. 27-46.

Schapera, Isaac (1947), Migrant labour and tribal life: A study of conditions in the Bechuanaland Protectorate, London: Oxford University Press.

Schneider, Leander (2006), 'The Maasai's new clothes: A developmentalist modernity and its exclusions', Africa Today, 53: 1, pp. 101-131.

Spear, Thomas T. and Waller, Richard (eds) (1993), Being Maasai: Ethnicity and identity in East Africa, London: James Currey. 
Syed, Ali (2007), “"Go West young man": The culture of migration among Muslims in Hyderabad, India', Journal of Ethnic and Migration Studies, 33: 1, pp. 37-58.

Tsing, Anna L. (1993), In the realm of the diamond queen: Marginality in an out-of-the-way place, Princeton: Princeton University Press.

United Nations Development Program (2009), Human development report 2009. Overcoming barriers: Human mobility and development, New York: United Nations Development Program.

Urban, Greg (2001), Metaculture: How culture moves through the world, Minneapolis: University of Minnesota Press.

Walker, John and Lion, Ras (2007), Bitozi, Dar es Salaam: Grandmaster.

Weiss, Brad (2002), 'Thug realism: Inhabiting fantasy in urban Tanzania', Cultural Anthropology, 17: 1, pp. 1-32.

West, Mustafa W. (2007), Welcome back, Dar es Salaam: Wananchi Video.

\section{SUGGESTED CITATION}

Salazar, B. N. (2010), 'Towards an anthropology of cultural mobilities', Crossings: Journal of Migration and Culture 1, pp. 53-68, doi: 10.1386/ cjmc.1.53_1

\section{CONTRIBUTOR DETAILS}

Noel B. Salazar obtained his Ph.D. from the Department of Anthropology at the University of Pennsylvania (USA). He is currently Postdoctoral Fellow at the Faculty of Social Sciences, University of Leuven (Belgium) and Visiting Research Associate at the Centre for Tourism and Cultural Change, Leeds Metropolitan University (UK). Dr. Salazar's research interests include anthropologies of mobility, the local-to-global nexus, discourses and imaginaries of Otherness, cultural brokering and cosmopolitanism. He has published widely, in various languages, and is the author of Envisioning Eden: Mobilizing Imaginaries in Tourism and Beyond (Oxford: Berghahn Books 2010). More information about Dr. Salazar's research projects and publications is available online: http://kuleuven.academica.edu/NoelBSalazar/

Contact: Cultural Mobilities Research (CuMoRe), University of Leuven, Parkstraat 45, bus 3615, BE-3000 Leuven, Belgium. 